\title{
Epidemiology of the viral hepatitis $B$ and $C$ in female prisoners of Metropolitan Regional Prison Complex in the State of Goiás, Central Brazil
}

\author{
Láiza Alencar Santos Barros ${ }^{[1]}$, Grécia Carolina Pessoni ${ }^{[2]}$, Sheila Araújo Teles ${ }^{[2]}$, \\ Sandra Maria Brunini de Souza ${ }^{[2]}$, Marcos André de Matos ${ }^{[2]}$, Regina Maria Bringel Martins ${ }^{[1]}$, \\ Nativa Helena Alves Del-Rios ${ }^{[2]}$, Márcia Alves Dias de Matos ${ }^{[1]}$ \\ and Megmar Aparecida dos Santos Carneiro ${ }^{[2]}$
}

[1]. Instituto de Patologia Tropical e Saúde Pública, Universidade Federal de Goiás. Goiânia, GO. [2]. Faculdade de Enfermagem, Universidade Federal de Goiás. Goiânia, GO

\begin{abstract}
Introduction: Little information regarding hepatitis $\mathrm{B}$ virus (HBV) and hepatitis $\mathrm{C}$ virus (HCV) infections among Brazilian female prisoners exists. This study investigated the prevalence and risk factors associated with HBV and HCV infections and identified viral genotypes among female prisoners in Goiás, Central Brazil. Methods: Women incarcerated in the largest prison in the State of Goiás were invited to participate in the study. All female prisoners were interviewed and tested for the detection of hepatitis B surface antigen (HBsAg), antibodies against $\mathrm{HBsAg}$ (anti-HBs), against hepatitis B core antigen (anti-HBc), and antibody against HCV (anti-HCV) by ELISA. HBsAg and anti-HCV positive samples were tested for HBV DNA and HCV RNA and genotyped, respectively. Results: Participants $(\mathrm{n}=148 ; 98.6 \%)$ completed the study with an overall HBV prevalence of $18.9 \%$. Age $>30$ years, a low education level, sex with a sexually transmitted diseases carrier, and a male sexual partner serving in the same penitentiary were associated with HBV infections. Only $24 \%$ of the women were anti-HBs positive suggesting previous HBV vaccination. Nine female prisoners $(6.1 \%)$ were anti-HCV positive. Age $>40$ years, injecting drug use and length of incarceration were statistically associated with anti-HCV antibodies. Five samples were HCV RNA positive and classified as genotypes 1 (subtypes $1 \mathrm{a} ; \mathrm{n}=3$ and $1 b ; n=1$ ) and 3 (subtype $3 a ; n=1$ ). The HBsAg-reactive sample was HBV DNA positive and genotype A. Conclusions: These findings highlight the necessity of public policies to control hepatitis $\mathrm{B}$ and $\mathrm{C}$ infections and emphasize the importance of hepatitis $B$ vaccination in prison environments.
\end{abstract}

Keywords: Hepatitis B. Hepatitis C. female inmates. Prevalence. Genotypes. Associated factors.

\section{INTRODUCTION}

Hepatitis B virus (HBV) and hepatitis C virus (HCV) infections are serious global public health problems. It is estimated that there are 350 and 130 million chronic carriers of these viruses, respectively, which are also at risk of developing chronic hepatitis, cirrhosis, and hepatocellular carcinoma ${ }^{1,2}$.

Hepatitis B virus has been classified into eight genotypes (A-H) ${ }^{3}$, and six HCV genotypes (1-6) and multiple subtypes have already been described ${ }^{4}$. The genotypic groups have variable geographic distribution and have been used to trace transmission routes. Furthermore, the genetic diversity of these viruses seems to interfere in the effectiveness of antiviral treatment ${ }^{5,6}$.

The prison population is at high risk for acquiring infectious diseases such as hepatitis B and C. Further some investigations have identified these viruses as important causes of deaths related to chronic liver diseases in prisoners ${ }^{7,8}$. Many characteristics of

Address to: Dr ${ }^{\mathrm{a}}$ Megmar Aparecida dos Santos Carneiro. IPTSP/UFG. Rua 235 s/n, Setor Universitário, 74605-050 Goiânia, GO, Brasil.

Phone: 5562 3209-6129; Ramal: 6129

e-mail: megmar@iptsp.ufg.br

Received in 12/07/2012

Accepted in 11/01/2013 confined people, including low socioeconomic status, illicit drug use, and multiple sexual partners, are predictors of these infections. Therefore, most are already infected at the time of imprisonment, becoming a source of propagation and maintenance of these viruses in the prison setting ${ }^{9-11}$.

The majority of studies on HBV and HCV infections in the prison population have been carried out among male prisoners ${ }^{12-14}$. As such, the overall results of these studies generally reflect the characteristics of the dominant population. In Brazil, a continental country, the few available data on hepatitis B and C epidemiology in female prisoners are mainly from populations in the Southeast Region ${ }^{10,11,15}$. Thus, the purpose of this study was to investigate the prevalence and risk factors associated with $\mathrm{HBV}$ and $\mathrm{HCV}$ infections and to identify the genotypes of these viruses circulating in female prisoners of Goiás, Central Brazil.

\section{METHODS}

This was a cross-sectional study of the female population serving time in the Complexo Prisional of Aparecida de Goiânia, which represents the largest prison complex in the State of Goiás, Central Brazil ${ }^{16}$. From August 2007 to June 2008, all of the female inmates $(n=150)$ were invited to participate in the study; two refused to participate. Written informed consent 
was obtained from all 148 women who agreed to participate. The study was approved by the Ethics Committee of the Federal University of Goiás (Protocol Number: 074/06).

Participants were interviewed face to face on sociodemographic data and risk factors. After the interview, a blood sample was collected by venipuncture and tested by enzyme linked immunosorbent assay (ELISA) for detection of hepatitis B surface antigen ( $\mathrm{HBsAg}$ ), antibody to hepatitis B surface antigen (anti-HBs), antibody to hepatitis B core antigen (anti-HBc) (Hepanostika Uni-form Biomérieux, Netherlands), and hepatitis $\mathrm{C}$ virus antibody (anti-HCV) antibodies (Abbott Laboratories, Brazil). Samples weakly reactive to anti-HCV (ratio OD/cut-off $<3.0$ ) were retested by line immunoassay (INNO-LIA HCV Ab III, Innogenetics, Belgium).

Deoxyribonucleic acid (DNA) was extracted from $\mathrm{HBsAg}$ positive samples, and the Pre-S/S genome region was amplified using a semi-nested PCR assay ${ }^{17}$. Polymerase chain reaction (PCR) products were subjected to restriction fragment length polymorphism (RFLP) genotyping analysis ${ }^{18}$. The detection of viral ribonucleic acid (RNA) was carried out in all anti-HCVpositive samples by reverse transcription polymerase chain reaction (RT-PCR), using primers complementary to the $5^{\prime}$ non-coding region of the $\mathrm{HCV}$ genome ${ }^{19}$. The hepatitis $\mathrm{C}$ virus ribonucleic acid (HCV RNA)-positive samples were genotyped using a line probe assay (INNO-LiPA, Innogenetics, Belgium).

The HBV and HCV prevalence was estimated using a 95\% confidence interval $(95 \% \mathrm{CI})$. Initially, bivariate analysis was performed to determine the relation between the dependent variable (prevalence of $\mathrm{HCV}$ or HBV) and each independent variable, thus obtaining the prevalence ratios and respective confidence intervals of $95 \%$. Variables with value $p<0.10$ were included in the multivariate Poisson regression models. All analysis were performed using the Stata statistical Package v. 11.

\section{RESULTS}

The majority of female prisoners was $\leq 30$ years of age (60.1\%), had five-to-nine years of formal education (52.9\%) and reported a family income of less than or equal to one Brazilian minimum wage salary per month (65.2\%). Within the study population, $63 \%$ were born in Goiás and the remaining (37\%) were born in other Brazilian states. Approximately half of the participants $(46.6 \%)$ were married, $36.5 \%$ were single, and $16.9 \%$ were divorced/widowed.

As shown in Table 1, 28 (18.9\%) women were anti-HBc positive: 25 (16.9\%) had anti-HBc associated with anti-HBs, and $1(0.7 \%)$ had anti-HBc associated with HBsAg. Only 36 $(24.3 \%)$ women were positive for anti-HBs alone, suggesting previous vaccination against hepatitis B. Further nine inmates (6.1\%; 95\% CI: 3.0-11.6) were anti-HCV positive by ELISA and were confirmed by immunoblot.

Hepatitis B virus deoxyribonucleic acid (HBV DNA) was detected in the HBsAg positive sample, and genotype A was identified. HCV RNA was detected in five samples. Genotyping revealed the presence of genotype 1 , subtypes $1 \mathrm{a}(\mathrm{n}=3)$ and $1 \mathrm{~b}$ $(\mathrm{n}=1)$, and genotype 3 , subtype $3 \mathrm{a}(\mathrm{n}=1)$.
TABLE 1 - Prevalence of hepatitis $B$ virus and hepatitis $C$ virus serological markers in 148 inmates of the Metropolitan Regional Prison Complex of Goiás, 2007-2008.

\begin{tabular}{lccc}
\hline Serological markers & Number & Percentage & $\mathbf{9 5 \% C I}$ \\
\hline HBV & & & \\
HBsAg/anti-HBc & 1 & 0.7 & $(0.0-4.3)$ \\
anti-HBc/anti-HBs & 25 & 16.9 & $(11.4-24.1)$ \\
anti-HBc only & 2 & 1.3 & $(0.2-5.3)$ \\
any HBV infection marker & 28 & 18.9 & $(13.1-26.3)$ \\
anti-HBs & 36 & 24.3 & $(17.8-32.1)$ \\
HCV & & & \\
anti-HCV & 9 & 6.1 & $(3.0-11.6)$ \\
\hline
\end{tabular}

95\% CI: $95 \%$ confidence interval; $\mathbf{H B V}$ : hepatitis B virus; $\mathbf{H C V}$ : hepatitis C virus; HBsAg: hepatitis B surface antigen; anti-HBc: antibody to hepatitis B core antigen; anti-HBs: antibody to hepatitis B surface antigen; anti-HCV: Hepatitis C virus antibody

The 36 female prisoners positive for anti-HBs alone were excluded from the analysis of risk factors for HBV infection. Age over 30 years, lower education, injection drug use, sexually transmitted disease (STD) history, sex with an STD carrier and sex with a drug user were statistically associated with HBV infection $(\mathrm{p}<0.05)$ (Table 2). In addition to sex with a male prisoner $(\mathrm{p}=0.10)$, these variables were included in a multivariate Poisson regression model, and four were independently associated with HBV infection: age $>30$ years, lower education, sex with an STD carrier, and sex with a male prisoner (Table 3).

With regard to HCV infection, the following variables were statistically significant: age over 40 years, injection drug use, having sex with a drug user, and the number of prisons attended $(\mathrm{p}<0.05)$ (Table 2). In addition to illicit drug use $(p=0.09)$ and length of incarceration $(p=0.07)$, these variables were included in a multivariate Poisson regression model. Age over 40 years, injection drug use and length of incarceration were independently associated with HCV infection (Table 3 ).

\section{DISCUSSION}

The present investigation confirms that female prisoners have a high risk for hepatitis $\mathrm{B}$ and $\mathrm{C}$ infections. Seropositivity for HBV markers in our study (18.9\%) was three fold higher than that found in a female population aged 13 to 69 years in the Midwest Region of Brazil $(6.6 \%)^{20}$. Further, the present prevalence was higher than that found in female prisoners in São Paulo ( $\mathrm{n}=225 ; 8.4 \%$; 95\% CI: $5.3-13.0)^{15}$ but was similar to those reported by Stief et al. ${ }^{21}$ in Mato Grosso do $\mathrm{Sul}(\mathrm{n}=242$; 14\%; 95\% CI: 10-19.2) and in other countries such as England $(\mathrm{n}=400 ; 12.2 \% \text {; } 95 \% \text { CI: 9.3-16) })^{22}$, and the United States of America $\left(\mathrm{n}=555 ; 26 \%\right.$; 95\% CI: 24-27) ${ }^{23}$.

Although our study demonstrated that prevalence of hepatitis $\mathrm{C}$ among inmates $(6.1 \%)$ was 40 -fold higher than that reported in pregnant women in Goiânia City $(0.15 \%)^{24}$, but it was lower than those recorded by Strazza et al. ${ }^{11}(\mathrm{n}=290 ; 16.2 \% ; 95 \%$ CI: 12.3-21.1) and Miranda et al. ${ }^{10}(\mathrm{n}=121 ; 19 \% ; 95 \% \mathrm{CI}$ : 12.7-27.3) among female prisoners in southeastern Brazil and in other countries such as Italy $(\mathrm{n}=973 ; 38 \%$; $95 \% \mathrm{CI}$ : 34.9 $41.2)^{13}$, England ( $\mathrm{n}=9965 ; 24.2 \%$; CI 95\%: 23.4-25.1 ${ }^{25}$, Finland $(\mathrm{n}=388 ; 52 \% \text {; 95\% CI: 46.9-57.1 })^{26}$ and Australia $(\mathrm{n}=630$; $57.5 \%, 95 \%$ CI: $53.5-61.3)^{27}$. 
TABLE 2 - Univariate analysis of risk factors associated to hepatitis B infection and hepatitis Cinfection in female prisoners of the Metropolitan Regional Prison Complex of Goiás.

\begin{tabular}{|c|c|c|c|c|c|c|c|c|}
\hline$\frac{\text { Variable }}{\text { Age (years) }}$ & \multicolumn{2}{|c|}{$\begin{array}{c}\text { HBV }^{\mathrm{a}} \\
\text { Prevalence (\%) }\end{array}$} & $\begin{array}{c}\text { PR } \\
\text { (IC 95\%) } \\
\end{array}$ & $\begin{array}{c}\mathrm{p} \\
\text { value }\end{array}$ & \multicolumn{2}{|c|}{$\begin{array}{c}\text { HCV } \\
\text { Prevalence (\%) } \\
\end{array}$} & $\begin{array}{c}\text { PR } \\
\text { (IC 95\%) } \\
\end{array}$ & $\begin{array}{c}\mathbf{p} \\
\text { value }\end{array}$ \\
\hline $31-40$ & $9 / 30$ & 30.0 & $2.4(1.0-5.5)$ & 0.05 & $5 / 127$ & 3.9 & 1.0 & \\
\hline$>40$ & $11 / 19$ & 57.9 & $4.5(2.1-9.7)$ & $<0.01$ & $4 / 21$ & 19.0 & $4.9(1.4-16.6)$ & 0.01 \\
\hline$>9$ & $3 / 31$ & 9.7 & 1.0 & & $2 / 44$ & 4.5 & 1.0 & \\
\hline $5-9$ & $17 / 60$ & 28.3 & $2.9(0.9-9.3)$ & 0.06 & $4 / 77$ & 5.2 & $1.1(0.2-6.0)$ & 0.88 \\
\hline$<5$ & $7 / 19$ & 36.8 & $3.8(1.1-13.0)$ & 0.03 & $3 / 25$ & 12.0 & $2.6(0.47-14.8)$ & 0.27 \\
\hline \multicolumn{9}{|l|}{ Blood transfusion } \\
\hline no & $20 / 86$ & 23.3 & 1.0 & & $6 / 113$ & 5.3 & 1.0 & \\
\hline yes & $10 / 47$ & 21.3 & $0.7(0.4-1.4)$ & 0.37 & $5 / 66$ & 7.6 & $1.5(0.4-5.4)$ & 0.53 \\
\hline \multicolumn{9}{|c|}{ Sharing of hygiene itens } \\
\hline no & $14 / 49$ & 28.6 & 1.0 & & $3 / 64$ & 4.7 & 1.0 & \\
\hline yes & $13 / 59$ & 22.0 & $0.8(0.4-1.5)$ & 0.44 & $6 / 79$ & 7.6 & $1.6(0.4-6.2)$ & 0.48 \\
\hline \multicolumn{9}{|l|}{ Illicit drug use } \\
\hline no & $13 / 51$ & 25.5 & 1.0 & & $1 / 63$ & 1.6 & 1.0 & \\
\hline yes & $15 / 60$ & 25.0 & $1.0(0.5-1.9)$ & 0.95 & $8 / 84$ & 9.5 & $6.0(0.8-47.1)$ & 0.09 \\
\hline \multicolumn{9}{|c|}{ Injection drug use (IDU) } \\
\hline no & $16 / 86$ & 18.6 & 1.0 & & $7 / 118$ & 5.9 & 1.0 & \\
\hline yes & $12 / 24$ & 50.0 & $2.7(1.5-4.9)$ & $<0.01$ & $2 / 28$ & 7.1 & $1.2(0.3-5.5)$ & 0.81 \\
\hline
\end{tabular}

\section{Sex with STD carrier}

\begin{tabular}{|c|c|c|c|c|c|c|c|c|}
\hline no & $17 / 89$ & 19.1 & 1.0 & & $8 / 120$ & 6.7 & & \\
\hline yes & $10 / 18$ & 55.6 & $2.9(1.6-5.3)$ & $<0.01$ & $0 / 21$ & 0.0 & - & - \\
\hline \multicolumn{9}{|c|}{ Sex with male prisoner } \\
\hline no & $11 / 59$ & 18.6 & 1.0 & & $3 / 74$ & 4.1 & 1.0 & \\
\hline yes & $17 / 52$ & 32.7 & $1.7(0.9-3.4)$ & 0.10 & $6 / 73$ & 8.2 & $2.0(0.5-7.8)$ & 0.31 \\
\hline \multicolumn{9}{|c|}{ Sex with IDU } \\
\hline no & $20 / 92$ & 21.7 & 1.0 & & $5 / 122$ & 4.1 & 1.0 & \\
\hline yes & $7 / 14$ & 50.0 & $2.3(1.2-4.4)$ & 0.01 & $4 / 19$ & 21.1 & $5.1(1.5-17.5)$ & $<0.01$ \\
\hline \multicolumn{9}{|c|}{ Lenght of Incarceration (months) } \\
\hline$\leq 6$ & $14 / 66$ & 21.2 & 1.0 & & $2 / 80$ & 2.5 & 1.0 & \\
\hline$>6$ & $14 / 46$ & 30.4 & $1.4(0.8-2.7)$ & 0.27 & $7 / 68$ & 10.3 & $4.1(0.9-19.3)$ & 0.07 \\
\hline \multicolumn{9}{|c|}{ Number of prisons } \\
\hline$\leq 2$ & $21 / 93$ & 22.6 & 1.0 & & $5 / 121$ & 4.1 & 1.0 & \\
\hline$>2$ & $7 / 18$ & 38.9 & $1.7(0.9-3.4)$ & 0.12 & $4 / 25$ & 16.0 & $3.9(1.1-13.5)$ & 0.03 \\
\hline
\end{tabular}

95\% CI: 95\% confidence interval; PR: prevalence ratio; HBV: hepatitis B virus; HCV: hepatitis C virus; STD: sexually transmitted diseases; IDU: Injection drug use. ${ }^{a}$ denominators reflects the number of valid responses. 
TABLE 3 - Variables associated with hepatitis B infection and hepatitis C infection in female prisoners of the Metropolitan Regional Prison Complex of Goiás.

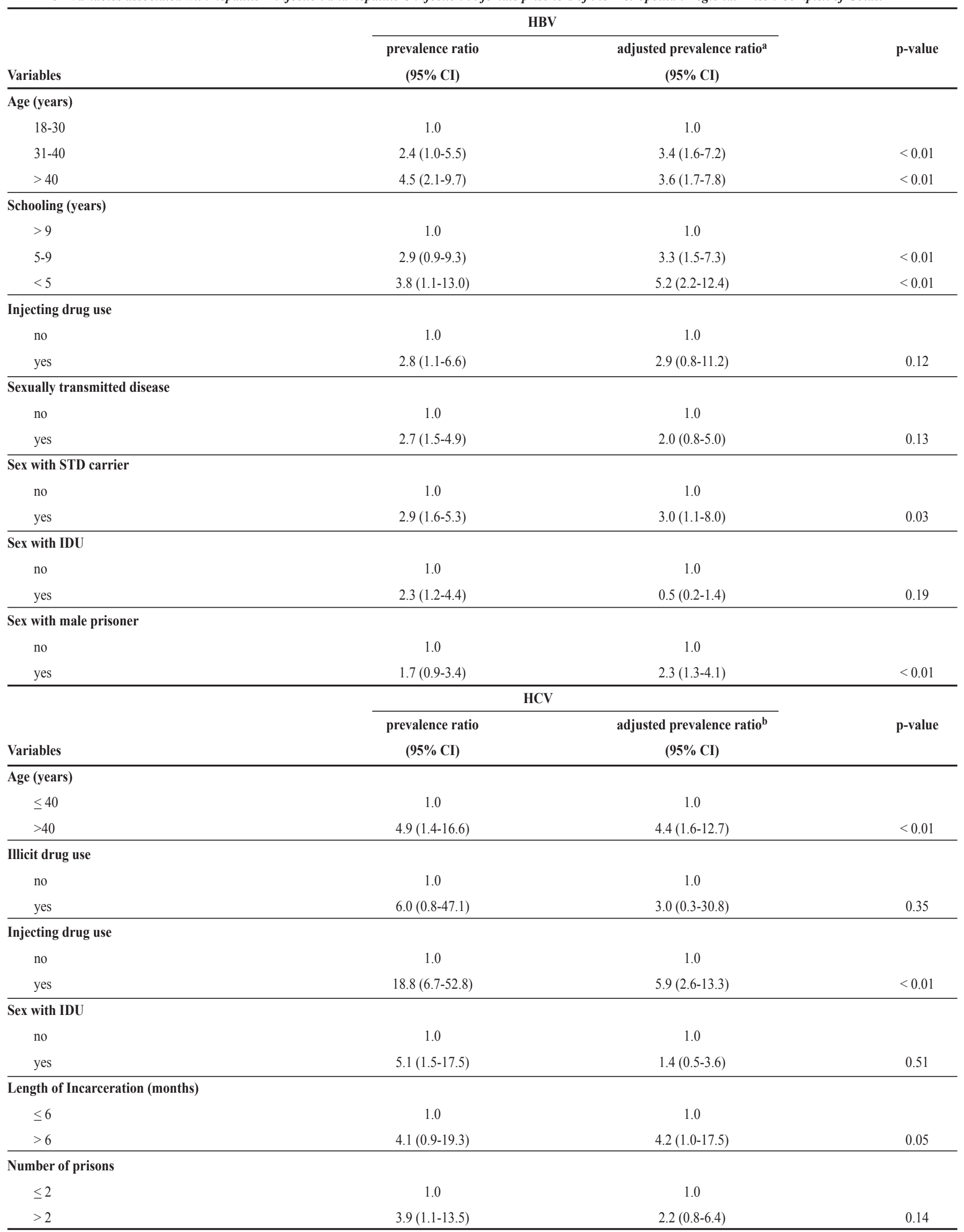

PR: prevalence Ratio; 95\% CI: 95\% confidence interval; HBV: hepatitis B virus; HCV: hepatitis C virus; STD: sexually transmitted diseases; IDU: Injection drug use; ${ }^{a}$ adjusted Prevalence Ratio by age, schooling, IDU, STD, Sex with STD carrier, sex with IDU and sex with male prisoner; badjusted Prevalence Ratio by age, illicit drug user, IDU, sex with IDU, length of incarceration, and number of prisons. 
Five of the nine anti-HCV-positive samples were also $\mathrm{HCV}$ RNA positive. These samples were genotyped as genotype 1, subtypes $1 \mathrm{a}(\mathrm{n}=3)$ and $1 \mathrm{~b}(\mathrm{n}=1)$, and genotype 3 , subtype $3 \mathrm{a}$ $(\mathrm{n}=1)$. Similarly, another study conducted in male prisoners from the same penitentiary complex found genotype 1 in $80 \%$ of the samples $(1 \mathrm{a}=60 \%)$, followed by genotype $3 \mathrm{a}(13.3 \%) 28$. In this sense, the HCV genotypes circulating in Goiás prisoners reflect the diversity of this virus in Goiás, Central Brazil29,30.

As observed elsewhere ${ }^{21,23,24}$, age was independently associated with $\mathrm{HBV}$ and $\mathrm{HCV}$ infections. In this investigation, the age association was evident among women $>30$ years old for hepatitis B, while HCV infection increased after age 40.

Hepatitis B virus is efficiently transmitted by sexual contact, while HCV is spread predominantly by parental routes ${ }^{1,2,31}$. The present findings highlight these assumptions. There was a significant association between HBV markers and sexual variables, including sex with an STD carrier (adjusted PR:3.0) and sex with a male serving time in the same penitentiary (adjusted PR: 2.3). By contrast, illicit injection drug use was a predictor of $\mathrm{HCV}$ infection (adjusted PR: 5.9), suggesting parenteral transmission of this virus.

Outbreaks of viral hepatitis are not unusual events in prisons $^{32-34}$. In this investigation, one female prisoner was HBsAg and HBV-DNA positive, and five were HCV RNA positive. These individuals may serve as reservoirs of $\mathrm{HBV}$ and $\mathrm{HCV}$ and may be potential transmitters of these viruses in the prison environment and their social network. In fact, a stricter association was found between HCV positivity and length of incarceration.

Although the hepatitis B vaccine has been recommended for prisoners since it became available in the $1980 \mathrm{~s}^{35}$, a low immunization rate is still observed in this group ${ }^{36}$. In Brazil, this vaccine has been recommended and free of charge for prisoners since the late 1990s. Nonetheless, only a low frequency of individuals vaccinated against hepatitis B has been observed. In Rio Claro (southern region) and Campo Grande (midwestern region), serologic evidence of previous vaccination was found in only $13.8 \%$ and $32.3 \%$ of the prisoners investigated, respectively 15,21 . Our investigation indicated a similar rate, as only $24 \%$ of the women were anti-HBs positive alone, suggesting previous vaccination against $\mathrm{HBV}$.

Our results should be considered with caution. This was a crosssectional study, and behavioral findings are based on self-reports. Although this study included $98.6 \%$ (148/150) of the female inmates of the largest prison Complex in State of Goiás, Central Brazil, they may not be representative of all women confined in this state.

Prisoners should be targeted for hepatitis B and C prevention and control programs. Serological screening at the time of admission and treatment of those with chronic hepatitis may contribute to the reduction of such infections in Brazilian prison settings. A safe and effective hepatitis B vaccine is available free of charge for this population, and investigations have reported a good acceptance of this vaccine among prisoners ${ }^{37}$. Therefore, the low $\mathrm{HBV}$ vaccination rate in this population should indicate that there is a need for interventions aimed at improving hepatitis $B$ vaccination in prison settings.

\section{ACKNOWLEDGMENTS}

The authors would like to thank the participating female prisoners, authorities and staff of the collaborating detention centers for making this survey possible.

\section{CONFLICT OF INTEREST}

The authors declare that there is no conflict of interest.

\section{FINANCIAL SUPPORT}

This work was financially supported by the Conselho Nacional de Desenvolvimento Cientifico e Tecnológico (CNPq).

\section{REFERENCES}

1. Lavanchy D. The global burden of hepatitis C. Liver Int 2009; 29 (suppl 1): 74-81.

2. Te HS, Jensen DM. Epidemiology of hepatitis B and C viruses: a global overview. Clin Liver Dis 2010; 14:1-21.

3. Kramvis A, Kew M, Francois G. Hepatitis B virus genotypes. Vaccine 2005; 23:2409-2423.

4. Simmonds P. Genetic diversity and evolution of hepatitis $\mathrm{C}$ virus- 15 years on. J Gen Virol 2004; 85:3173-3188.

5. Ghany MG, Strader DB, Thomas DL, Seeff LB. Diagnosis, management, and treatment of hepatitis C: an update. Hepatology 2009; 49:1335-1374.

6. Locarnini S, Zoulim F. Molecular genetics of HBV infection. Antivir Ther 2010; 15 (suppl 3):3-14.

7. Harzke AJ, Baillargeon J, Paar DP, Pulvino J, Murray OJ. Chronic liver disease mortality among male prison inmates in Texas, 1989-2003. Am J Gastroenterol 2009a; 104:1412-1419.

8. Harzke AJ, Baillargeon JG, Kelley MF, Diamond PM, Goodman KJ, Paar DP. HCV-related mortality among male prison inmates in Texas, 1994-2003. Ann Epidemiol 2009b; 19:582-589.

9. Macalino GE, Vlahov D, Dickinson BP, Schwartzapfel B, Rich JD. Community incidence of hepatitis B and C among reincarcerated women. Clin Infect Dis 2005; 41:998-1002.

10. Miranda AE, Vargas PM, St Louis ME, Viana MC. Sexually transmitted diseases among female prisoners in Brazil: prevalence and risk factors. Sex Transm Dis 2000; 27:491-495.

11. Strazza L, Massad E, Azevedo RS, Carvalho HB. Behavior associated with HIV and HCV infection in female prison inmates in Sao Paulo, Brazil. Cad Saude Publica 2007; 23:197-205.

12. Allwright S, Bradly F, Long J, Barry J, Thornton L, Parry J. Prevalence of antibodies to hepatitis B, hepatitis C, and HIV and risk factors in Irish prisoners: results of a national cross sectional survey. BMJ 2000; 321:78-82.

13. Babudieri S, Longo B, Sarmati L, Starnini G, Dori L, Suligoi B, et al. Correlates of $\mathrm{HIV}, \mathrm{HBV}$, and $\mathrm{HCV}$ infections in a prison inmate population: results from a multicentre study in Italy. J Med Virol 2005; 76:311-317.

14. Hellard ME, Hocking JS, Crofts N. The prevalence and the risk behaviours associated with the transmission of hepatitis $\mathrm{C}$ virus in Australian correctional facilities. Epidemiol Infect 2004; 132:409-415.

15. Berra JA, Bacetti LB, Buzo AA. Seroprevalence of HIV, syphilis, and hepatitis $\mathrm{B}$ and $\mathrm{C}$ among women confined at Centro de Ressocialização de Rio Claro, São Paulo. Rev Inst Adolfo Lutz 2006; 65:133-136.

16. Superintendência do Sistema de Execução Penal (SUSEPE) do Estado de Goiás. Goiânia:http://www.agsep.go.gov.br/projetos-2/07/08/2012/dados-estatisticos.

17. Motta-Castro AR, Martins RM, Yoshida CF, Teles SA, Paniago AM, Lima $\mathrm{KM}$, et al. Hepatitis B virus infection in isolated Afro-Brazilian communities. J Med Virol 2010; 77:188-193. 
18. Araujo NM, Mello FC, Yoshida CF, Niel C, Gomes SA. High proportion of subgroup A' (genotype A) among Brazilian isolates of hepatitis B virus. Arch Virol 2004; 149:1383-1395.

19. Ginabreda MG, Yoshida CF, Niel C. Genomic characterization of Brazilian hepatitis C virus genotypes 1a and 1b. Braz J Med Biol Res 1997; 30:339-345.

20. Pereira LM, Martelli CM, Merchan-Hamann E, Montarroyos UR, Braga MC, Lima ML, et al. Population-based multicentric survey of hepatitis B infection and risk factor differences among three regions in Brazil. Am J Trop Med Hyg 2009; 81:240-247.

21. Stief AC, Martins RM, Andrade SM, Pompilio MA, Fernandes SM, Murat PG, et al. Seroprevalence of hepatitis B virus infection and associated factors among prison inmates in state of Mato Grosso do Sul, Brazil. Rev Soc Bras Med Trop 2010; 43:512-515

22. Weild AR, Gill ON, Bennett D, Livingstone SJ, Parry JV, Curran L. Prevalence of HIV, hepatitis B, and hepatitis C antibodies in prisoners in England and Wales: a national survey. Commun Dis Public Health 2000; 3:121-126.

23. Hennessey KA, Kim AA, Griffin V, Collins NT, Weinbaum CM, Sabin K. Prevalence of infection with hepatitis $\mathrm{B}$ and $\mathrm{C}$ viruses and co-infection with HIV in three jails: a case for viral hepatitis prevention in jails in the United States. J Urban Health 2009; 86:93-105.

24. Costa ZB, Machado GC, Avelino MM, Gomes Filho C, Macedo Filho JV, Minuzzi AL, et al. Prevalence and risk factors for Hepatitis C and HIV-1 infections among pregnant women in Central Brazil. BMC Infect Dis 2009; 9:116.

25. Kirwan P, Evans B, Brant L. Hepatitis C and B testing in English prisons is low but increasing. J Public Health (Oxf) 2011; 33:197-204.

26. Viitanen P, Vartiainen H, Aarnio J, von Gruenewaldt V, Hakamaki S, Lintonen T, et al. Hepatitis A, B, C and HIV infections among Finnish female prisoners - Young females a risk group. J Infect 2011; 62:59-66.

27. Hellard ME, Hocking JS, Crofts N. The prevalence and the risk behaviours associated with the transmission of hepatitis $\mathrm{C}$ virus in Australian correctional facilities. Epidemiol Infect 2004; 132:409-415.
28. Gonçalves KK. História de vida e situação de saúde no ambiente prisional de Goiás: Estudo da prevalência de hepatite C em detentos. Mestrado em Ciências Ambientais e Saúde. Ciências da Saúde. Goiânia: Pontifícia Universidade Católica de Goiás, 2005.

29. Campiotto S, Pinho JR, Carrilho FJ, da Silva LC, Souto FJ, Spinelli V, et al. Geographic distribution of hepatitis C virus genotypes in Brazil. Braz J Med Biol Res 2005; 38:41-49.

30. Martins RM, Teles SA, Freitas NR, Motta-Castro AR, Souto FJ, Mussi A, et al. Distribution of hepatitis $\mathrm{C}$ virus genotypes among blood donors from mid-west region of Brazil. Rev Inst Med Trop Sao Paulo 2006; 48:53-55.

31. Alter MJ. Epidemiology and prevention of hepatitis B. Semin Liver Dis 2003; 23:39-46.

32. Centers for Disease Control and Prevention (CDC). Hepatitis B outbreak in a state correctional facility, 2000. MMWR Morb Mortal Wkly Rep 2001; 50:529532.

33. Hutchinson SJ, Goldberg DJ, Gore SM, Cameron S, McGregor J, McMenamin J, McGavigan J. Hepatitis B outbreak at Glenochil prison during January to June 1993. Epidemiol Infect 1998; 121:185-191.

34. Kar P, Gangwal P, Budhiraja B, Singhal R, Jain A, Madan K, et al. Analysis of serological evidence of different hepatitis viruses in acute viral hepatitis in prisoners in relation to risk factors. Indian J Med Res 2000; 112:128-132.

35. Centers for Disease Control and Prevention (CDC). Recommendation of the Immunization Practices Advisory Committee (ACIP): inactivated hepatitis B virus vaccine. MMWR Morb Mortal Wkly Rep 1982; 31:317-322.

36. Vallabhaneni S, Macalino GE, Reinert SE, Schwartzapfel B, Wolf FA, Rich JD. Prisoners' attitudes toward Hepatitis B vaccination. Prev Med 2004; 38 : 828-833.

37. Clarke J, Schwartzapfel B, Pomposelli J, Allen S, Spaulding A, Rich JD. Hepatitis B vaccination of incarcerated women: a pilot program. J Health Care Poor Underserved 2003; 14:318-323. 